\title{
ANALISIS KEMAMPUAN BERPIKIR KRITIS SISWA KELAS V DALAM PEMBELAJARAN IPA DI SDN KARANG TENGAH 11 KOTA TANGERANG
}

\author{
${ }^{1}$ Aisah Amalia, ${ }^{2}$ Candra Puspita Rini, ${ }^{3}$ Aam Amaliyah \\ ${ }_{1,2,3}$ Universitas Muhammadiyah Tangerang
}

Email: $\underline{{ }^{1} \text { amaliasyah30@gmail.com, }}{ }^{2}$ candrapuspitarini@gmail.com, $\underline{{ }^{3} \text { aam.umt @ gmail.com }}$

\begin{abstract}
Abstrak
Penelitian ini bertujuan untuk mengetahui kemampuan berpikir kritis siswa kelas $\mathrm{V}$ dalam pembelajaran IPA di SDN Karang Tengah 11 dan faktor-faktor yang mempengaruhi kemampuan berpikir kritis siswa kelas V dalam Pembelajaran IPA di SDN Karang Tengah 11. Fokus penelitian ini adalah kemampuan berpikir kritis siswa kelas V dalam pembelajaran IPA di SDN Karang Tengah 11 dan faktor-faktor yang mempengaruhi kemampuan berpikir kritis siswa kelas V dalam pembelajaran IPA di SDN Karang Tengah 11. Penelitian ini menggunakan metode penelitian deskriptif kualitatif. Subjek dalam penelitian ini adalah siswa kelas VB SDN Karang Tengah 11 Kota Tangerang. Diantaranya siswa kategori kemampuan berpikir kritis tinggi, siswa kategori kemampuan berpikir kritis sedang dan siswa kategori kemampuan berpikir kritis rendah. Teknik pengumpulan data dalam penelitian ini adalah observasi, tes, wawancara dan dokumentasi. Hasil penelitian menunjukkan siswa dengan kategori kemampuan berpikir kritis tinggi dapat memenuhi semua indikator berpikir kritis, siswa dengan kategori kemampuan berpikir kritis sedang mampu memenuhi tiga indikator berpikir kritis dan siswa dengan kategori kemampuan berpikir kritis rendah hanya mampu memenuhi dua indikator berpikir kritis rendah. Hal ini juga dikarenakan adanya beberapa faktor yang memepengaruhi kemampuan berpikir rkitis siswa yaitu sebagai berikut : faktor internal seperti faktor kondisi fisik, motivasi, kecemasan, perkembangan intelektual dan interaksi dan faktor eksternal berhubungan dari luar individu berupa lingkungan sosial.
\end{abstract}

Kata kunci: Kemampuan Berpikir Kritis, Pembelajaran IPA, faktor-faktor penyebab

\begin{abstract}
This study aims to determine the critical thinking skills of fifth grade students in science learning at SDN Karang Tengah 11 and the factors that influence the critical thinking skills of fifth grade students in science learning at Karang Tengah 11 elementary school. The focus of this research is on the critical thinking skills of fifth grade students. in learning science at SDN Karang Tengah 11 and the factors that affect the critical thinking skills of grade 5 students in learning science at SDN Karang Tengah 11. This study uses descriptive qualitative research methods. The subjects in this study were students of class VB at SDN Karang Tengah 11, Tangerang City. Among them are students in the category of high critical thinking skills, students in the category of moderate critical thinking abilities and students in the category of low critical thinking abilities. Data collection techniques in this study were observation, tests, interviews and documentation. The results showed that students with high critical thinking ability category could fulfill all critical thinking indicators, students with moderate critical thinking ability category were able to fulfill three critical thinking indicators and students with low critical thinking ability category were only able to meet two low critical thinking indicators. This is also because there are several factors that influence students' critical thinking skills, namely as follows: internal factors such as physical condition factors, motivation, anxiety, intellectual development and interaction and external factors related from outside the individual in the form of the social environment.
\end{abstract}

Keywords: Critical Thinking Ability, Science Learning, causal factors 


\section{PENDAHULUAN}

Kemampuan sebagai suatu dasar seseorang dalam melakukan segala macam kegiatan, setiap orang memiliki kecakapan untuk menyelesaikan pekerjaannya atau menguasai hal-hal yang ingin dikerjakan dalam suatu aktivitas sehingga bisa efektif dan tentunya efisien dalam menguasai keahlian dan mengerjakan beragam tugas dalam suatu pekerjaan atau suatu penilaian atas tindakan seseorang (Astuti, 2015 hal 71)

Berpikir kritis dapat dikatakan sebuah kemampuan yang dimiliki setiap orang untuk menganalisis ide atau gagasan kearah yang lebih spesifik untuk mengejar pengetahuan yang relevan dengan melibatkan bukti (Susanto, 2016 hal 121).

Sehubungan dengan perkembangan jaman yang semakin maju, menuntut siswa untuk mampu berpikir kritis menghadapi perubahan yang terjadi. Kemampuan berpikir kritis bertujuan memperlancar paradigma pembelajaran saat ini. Berpikir kritis merupakan hal penting yang harus dimiliki dalam membangun pengetahuan siswa. Kemampuan berpikir kritis akan merangsang penalaran kognitif siswa dalam memperoleh pengetahuan.

Tujuan berpikir kritis yaitu untuk menguji suatu pendapat atau ide melalui pemahaman yang mendalam. Siswa harus menitikberatkan pada usaha berpikir untuk aktif menganalisis dan memecahkan berbagai masalah yang ada disekitar siswa yang termasuk dalam proses belajar siswa (Trimahesri dan Hardini, 2019 hal 113)

Adapun indikator-indikator berpikir kritis terdapat lima aspek. Lima aspek tersebut merupakan indikator seseorang telah berpikir kritis Ennis (dalam Wijayanti dan Siswanto 2020: 110). Kelima kategori tersebut diuraikan menjadi beberapa bagian sebagai berikut : Indikator kemampuan berpikir kritis yang diukur dalam penelitian ini yaitu: sebagai berikut : (1) memberikan penjelasan sederhana, (2) membangun keterampilan dasar, (3) menympulkan, (4) memberikan penjelasan lanjut, (5) mengatur strategi dan taktik.

Faktor-faktor yang Mempengaruhi Kemampuan Berpikir Kritis

Pencapaian yang baik dari berpikir kritis siswa pada pembelajaran dipengaruhi oleh beberapa faktor. Kemampuan berpikir kritis setiap orang berbeda-beda. Ada beberapa faktor yang mempengaruhi kemampuan berpikir kritis siswa adalah sebagai berikut: Faktor pertama yang mempengaruhi kemampuan berpikir kritis yaitu kondisi fisik. ketika seseorang dalam kondisi sakit, sedangkan ia dihadapkan pada kondisi yang menuntut pemikiran matang untuk memecahkan suatu masalah, tentu kondisi seperti ini sangat mempengaruhi pikirannya sehingga seseorang tidak dapat berkonsentrasi dan berpikir cepat, faktor kedua yang mempengaruhi kemampuan berpikir kritis yaitu motivasi. Motivasi merupakan dorongan yang ada didalam diri seseorang untuk berusaha menumbuhkan minat belajar siswa, dengan tumbuhnya minat belajar siswa maka tujuan pembelajaran dapat tercapai dengan mudah, faktor ketiga yang dapat mempengaruhi kemampuan berpikir kritis siswa yaitu kecemasan. Kecemasan merupakan keadaan emosional seseorang terhadap suatu kemungkinan yang dapat membahayakan dirinya atau orang lain, faktor keempat yang dapat mempengaruhi kemampuan berpikir kritis yaitu perkembangan intelektual. Perkembangan intelektual siswa berbeda antara satu siswa dengan yang lain. Ada beberapa faktor yang 


\section{Sibcitie Jourral}

Jurnal Ilmiah Bioang Sosial, Thonomi, Budaya, Tekuologi, dan Pendidikan

mempengaruhi perkembangan intelektual siswa. Perkembangan intelektual juga dipengaruhi oleh usia siswa itu sendiri. faktor kelima yang dapat mempengaruhi kemampuan berpikir kritis yaitu interaksi. Suasana pembelajaran yang kondusif akan meningkatkan semangat siswa dalam proses pembelajaran sehingga siswa dapat berkonsentrasi dalam memecahkan masalah (Prameswari, dkk., 2018 hal 747).

IPA atau sains merupakan suatu proses yang menghasilkan pengetahuan. Proses tersebut bergantung pada proses observasi yang cermat terhadap fenomena dan pada teoriteori temuan untuk memaknai hasil observasi tersebut (Rustaman, 2018 hal 1)

Selanjutnya tujuan IPA dapat memberikan keterampilan, kemampuan, sikap ilmiah, pemahaman, kebiasaan dan apresiasi. Seseorang yang belajar tentang IPA dapat menghargai lingkungan sekitarnya atas ciptaan Tuhan dengan begitu mereka dapat menjaga lingkungan sekitar (Trianto, 2010 hal 142)

Karakteristik pembelajaran IPA di Sekolah Dasar dilakukan dengan sistem belajar kelompok, menggunakan prinsip hands on dan minds on. Melatih siswa terkait keterampilan proses sains, fokus pada penanaman konsep, prinsip, hukum dan teori, pembelajaran dilakukan di dalam dan luar kelas, pembelajaran dilakukan secara menyenangkan dan berpusat siswa (Wijaya, 2018 hal 150)

Penelitian ini bertujuan untuk mengetahui kemampuan berpikir kritis siswa kelas $\mathrm{V}$ dalam pembelajaran IPA di SDN Karang Tengah 11 dan mengetahui apa saja faktor yang mempengaruhi kemampuan berpikir kritis siswa kelas V di SDN karang Tengah 11

\section{METODE}

Penelitian ini menggunakan metode kualitatif. Pendekatan penelitian kualitatif dengan bentuk deskriptif kualitatif. Menurut Sanjaya (2013:47) menyatakan bahwa "penelitian deskriptif kualitatif adalah metode penelitian yang bertujuan untuk menggambarkan secara utuh dan mendalam tentang realitas sosial dan berbagai fenomena yang terjadi di masyarakat yang menjadi subyek penelitian sehingga tergambarkan ciri, karakter, sifat, dan model dari fenomena tersebut". Lokasi penelitian ini dilaksanakan di SDN Karang Tengah 11 Kota Tangerang. Subjek penelitian ini adalah 9 siswa yang telah dikelompokkan dengan kategori tinggi, sedang dan rendah.

Instrumen kemampuan berpikir kritis yang digunakan pada penelitian ini menggunakan soal uraian pada materi organ pernapasan pada manusia dan hewan. Dengan jumlah soal sebanyak 5 buah. Adapun kemampuan berpikir kritis yang diukur pada penelitian ini terdiri dari lima aspek, yaitu :

1) Memberikan penjelasan sederhana, yang terdiri dari dari sub indikator : memfokuskan pertanyaan, menganalisis pertanyaan, bertanya dan menjawab pertanyaan

2) Membangun keterampilan sederhana yang terdiri dari sub indikator: Mempertimbangkan apakah sumber dapat dipercaya atau tidak, Mengobservasi, mempertimbangkan laporan observasi. 
3) Menyimpulkan yang terdiri dari sub indikator: Melakukan dan mempertimbangkan hasil deduksi, melakukan dan mempertimbangkan hasil induksi, membuat dan menentukan nilai pertimbangan.

4) Memberikan penjelasan lebih lanjut yang terdiri dari sub indikator: mendefinisikan, mempertimbangkan suatu definisi, mengidentifikasi asumsi-asumsi.

5) Mengatur strategi dan taktik yang terdiri dari sub indikator: menentukan suatu tindakan, berinteraksi dengan orang lain.

Penelitian ini menggunakan teknik dan alat pengumpulan data yang berupa teknik observasi untuk mengetahui kemampuan berpikir kritis siswa dalam pembelajaran IPA, teknik pengkuran berupa soal tes yang mengacu pada indikator berpikir kritis, teknik komunikasi langsung berupa pedoman wawancara dan teknik dokumentasi berupa foto-foto dokumen resmi serta kegiatan selama penelitian.

Teknik analisis data pada penelitian ini yaitu menggunakan teknik analisis data menurut Miles dan Huberman (Sugiyono 2018:244) mengemukakan bahwa "teknik analisis data adalah proses mencari dan menyusun secara sistematis data yang diperoleh dari hasil wawancara, catatan lapangan, dan dokumentasi, dengan cara mengorganisasikan data ke dalam kategori, menjabarkan ke dalam unit-unit, melakukan sintesa, menyusun ke dalam pola, memilih mana yang pentinng dan yang akan dipelajari, dan membuat kesimpulan sehingga mudah di pahami oleh diri sendiri maupun orang lain" adapun aktivitas dalam analisis data penelitian ini yakni reduksi data, penyajian data, dan menyimpulkan (Sugiyono, 2018:244).

\section{HASIL PEMBAHASAN}

\section{Isi Hasil Pembahasan}

Berdasarkan data penelitian yang diperoleh dari 3 subjek dengan kategori kemampuan berpikir berpikir kritis tinggi, sedang dan rendah dapat dipaparkan sebagai berikut:

\section{Subjek 1}

Berdasarkan hasil tes yang sudah dilakukan kepada subjek 1, didapatkan ringkasan data hasil tes kemampuan berpikir kritis seperti pada Tabel 1.

Tabel 1 Paparan Data Hasil Tes Kemampuan Berpikir Kritis Subjek 1 tingkat kemampuan berpikir kritis tinggi

\begin{tabular}{ll}
\hline Indikator Kemampuan Berpikir Kritis & \multicolumn{1}{c}{ Uraian } \\
\hline Memberikan penjelasan sederhana & $\begin{array}{l}\text { S1 mampu merumuskan pertanyaan } \\
\text { yang sudah mengarah pada masalah di } \\
\text { pernyataan }\end{array}$ \\
\hline Membangun keterampilan dasar & $\begin{array}{l}\text { S1 mampu memberikan alasan terhadap } \\
\text { pendapat yang dikemukakan dengan } \\
\text { alasan yang sudah mengarah pada soal. }\end{array}$ \\
\hline
\end{tabular}




\section{Sibatile Jocumal}

Jurnal Ilmiab Bioang Sosial, Tkonomi, Budaya, Tekuologi, dan Pendidikan

Menyimpulkan

Membuat penjelasan lebih lanjut

Mengatur strategi dan taktik
S1 mampu menganalisis pertanyaan dan teliti dalam menjawab soal. Siswa pada kategori sudah dapat menuliskan kesimpulan dengan benar

S1 mampu menganalisis dan memberikan penjelasan terhadap soal yang disajikan

S1 mampu menunjukkan posisi setuju atau tidak terhadap suatu argumen sesuai dengan pernyataan dengan alasan yang sesuai.

Berdasarkan transkip wawancara yang telah dilakukan kepada subjek 1, terkait dengan pengalian informasi sebagaimana diuraikan di atas, maka diperoleh ringkasan hasil wawancara kemampuan berpikir kritis, seperti pada tabel 2.

Tabel 2 Ringkasan hasil wawancara subjek 1

tingkat kemampuan berpikir kritis tinggi

Indikator Kemampuan Berpikir Kritis

Memberikan penjelasan sederhana

\section{Uraian}

S1 mampu menjelaskan soal tersebut dengan bahasanya sendiri, mampu merumuskan pertanyaan dan memfokuskan pertanyaan pada soal 1 dengan benar.

Membangun keterampilan dasar $\quad S 1$ mampu memberikan alasan terkait jawaban yang subjek tulis pada soal tes.

Menyimpulkan S1 mampu menyebutkan kesimpulan dari permasalahan pada soal 3 dengan benar dan lengkap.

Membuat penjelasan lebih lanjut S1 mampu memberikan penjelasan sesuai dengan soal, dengan benar dan lengkap

Mengatur strategi dan taktik
S1 mampu menjelaskan dengan baik langkah penyelesaian yang sudah ditemukan pada soal nomor 5 juga mampu menentukan suatu tindakan terhadap suatu argumen sesuai dengan pernyataan dengan alasan yang sesuai. 
Pada indikator memberikan penjelasan sederhana dari hasil tes dan wawancara diketahui S1 mampu merumuskan pertanyaan atau permasalahan pada soal 1 dengan benar.

Pada indikator membangun keterampilan sederhana dari hasil tes dan wawancara S1 mampu memberikan alasan dengan benar dan lengkap terhadap pendapat yang dikemukakan.

Pada indikator menyimpulkan berdasakan jawaban siswa tersebut menunjukkan bahwa kemampuan berpikir kritis siswa pada indikator menyimpulkan baik, karena S1 mampu menganalisis pertanyaan dan teliti dalam menjawab soal. S1 sudah dapat menuliskan kesimpulan dengan benar.

Pada indikator memberikan penjelasan lebih lanjut siswa mampu menganalisis dan memberikan penjelasan terhadap soal yang disajikan.

Pada indikator mengatur strategi dan taktik siswa diminta untuk menentukan suatu tindakan pada permasalahan dalam soal. Siswa mampu menunjukkan posisi setuju atau tidak terhadap suatu argumen sesuai dengan pernyataan dengan alasan yang sesuai.

\section{Subjek 2}

Tabel 3 Paparan Data Hasil Tes Kemampuan Berpikir Kritis Subjek 2 tingkat kemampuan berpikir kritis sedang

\begin{tabular}{ll}
\hline Indikator Kemampuan Berpikir Kritis & \multicolumn{1}{c}{ Uraian } \\
\hline Memberikan penjelasan sederhana & S2 belum mampu merumuskan \\
& pertanyaan atau permasalahan pada \\
& soal 1 dengan benar dan lengkap \\
\hline Membangun keterampilan dasar & S2 mampu memberikan alasan \\
& terhadap pendapat yang dikemukakan \\
dengan alasan yang sudah mengarah
\end{tabular}

Berdasarkan transkip wawancara yang telah dilakukan kepada subjek 2, terkait dengan pengalian informasi sebagaimana diuraikan di atas, maka diperoleh ringkasan hasil wawancara kemampuan berpikir kritis, seperti pada tabel 4 


\section{Sibatile Jowrmal}

Jurnal Ilmiah Bioang Sosial, Thonomi, Budaya, Tekuologi, dan Pendidikan

Tabel 4 Ringkasan hasil wawancara subjek 2

tingkat kemampuan berpikir kritis sedang

\section{Indikator Kemampuan Berpikir Kritis \\ Memberikan penjelasan sederhana}

\section{Uraian}

S2 belum mampu menjelaskan soal tersebut dengan bahasanya sendiri, mampu merumuskan pertanyaan dan memfokuskan pertanyaan pada soal 1 dengan benar.

Membangun keterampilan dasar

S2 mampu memberikan alasan terkait jawaban yang subjek tulis pada soal tes.

\section{Menyimpulkan}

S2 belum mampu menyebutkan kesimpulan dari permasalahan pada soal 3 dengan benar dan lengkap.

Membuat penjelasan lebih lanjut S2 belum mampu memberikan penjelasan sesuai dengan soal, dengan benar dan lengkap

Mengatur strategi dan taktik langkah penyelesaian yang sudah ditemukan pada soal nomor 5 juga mampu menentukan suatu tindakan terhadap suatu argumen sesuai dengan pernyataan dengan alasan yang sesuai.

Pada indikator memberikan penjelasan sederhana dari hasil tes dan wawancara diketahui S2 belum mampu merumuskan pertanyaan atau permasalahan pada soal 1 dengan benar.

Pada indikator membangun keterampilan sederhana dari hasil tes dan wawancara S2 mampu memberikan alasan dengan benar dan lengkap terhadap pendapat yang dikemukakan.

Pada indikator menyimpulkan berdasakan jawaban siswa tersebut menunjukkan bahwa s2 belum mampu menganalisis pertanyaan dan teliti dalam menjawab soal. Siswa sudah dapat menuliskan kesimpulan dengan benar.

Pada indikator memberikan penjelasan lebih lanjut s2 belum mampu menganalisis dan memberikan penjelasan terhadap soal yang disajikan.

Pada indikator mengatur strategi dan taktik siswa diminta untuk menentukan suatu tindakan pada permasalahan dalam soal. S2 mampu menunjukkan posisi setuju atau tidak terhadap suatu argumen sesuai dengan pernyataan dengan alasan yang sesuai. 


\section{Subjek 3}

Tabel 5 Paparan Data Hasil Tes Kemampuan Berpikir Kritis Subjek 3 tingkat kemampuan berpikir kritis rendah

\begin{tabular}{ll}
\hline Indikator Kemampuan Berpikir Kritis & \multicolumn{1}{c}{ Uraian } \\
\hline Memberikan penjelasan sederhana & $\begin{array}{l}\text { S3 belum mampu merumuskan } \\
\text { pertanyaan atau permasalahan pada } \\
\text { soal 1 dengan benar dan lengkap }\end{array}$ \\
\hline Membangun keterampilan dasar & S3 mampu memberikan alasan \\
& terhadap pendapat yang dikemukakan \\
dengan alasan yang sudah mengarah & pada soal. \\
\hline Menyimpulkan & \\
\hline Membuat penjelasan lebih lanjut & $\begin{array}{l}\text { S3 belum mampu menyimpulkan } \\
\text { dengan tepat }\end{array}$ \\
\hline S3 belum mampu menganalisis dan \\
memberikan penjelasan terhadap soal \\
yang disajikan \\
\hline S3 mampu menunjukkan posisi setuju \\
atau tidak terhadap suatu argumen \\
sesuai dengan pernyataan dengan \\
alasan yang sesuai.
\end{tabular}

Berdasarkan transkip wawancara yang telah dilakukan kepada subjek 3, terkait dengan pengalian informasi sebagaimana diuraikan di atas, maka diperoleh ringkasan hasil wawancara kemampuan berpikir kritis, seperti pada tabel 6 .

Tabel 6 Ringkasan hasil wawancara subjek 1

tingkat kemampuan berpikir kritis rendah

\begin{tabular}{ll}
\hline Indikator Kemampuan Berpikir Kritis & Uraian \\
\hline Memberikan penjelasan sederhana & S3 belum mampu merumuskan \\
pertanyaan dan memfokuskan \\
pertanyaan pada soal 1 dengan \\
benar.
\end{tabular}




\section{Sibcitile Jocurnal}

Jurnal Ilmiah Bioang Sosial, Thonomi, Budaya, Tekuologi, dan Pendidikan

Membuat penjelasan lebih lanjut

Mengatur strategi dan taktik
S3 belum mampu memberikan penjelasan sesuai dengan soal, dengan benar dan lengkap

S3 mampu menjelaskan dengan baik langkah penyelesaian yang sudah ditemukan pada soal nomor 5 juga mampu menentukan suatu tindakan terhadap suatu argumen sesuai dengan pernyataan dengan alasan yang sesuai.

Pada indikator memberikan penjelasan sederhana dari hasil tes dan wawancara diketahui S3 belum mampu merumuskan pertanyaan atau permasalahan pada soal 1 dengan benar.

Pada indikator membangun keterampilan sederhana dari hasil tes dan wawancara S3 mampu memberikan alasan dengan benar dan lengkap terhadap pendapat yang dikemukakan.

Pada indikator menyimpulkan berdasakan jawaban siswa tersebut menunjukkan bahwa S3 belum mampu menganalisis pertanyaan dan teliti dalam menjawab soal. Siswa sudah dapat menuliskan kesimpulan dengan benar.

Pada indikator memberikan penjelasan lebih lanjut S3 belum mampu menganalisis dan memberikan penjelasan terhadap soal yang disajikan.

Pada indikator mengatur strategi dan taktik siswa diminta untuk menentukan suatu tindakan pada permasalahan dalam soal. S3 mampu menunjukkan posisi setuju atau tidak terhadap suatu argumen sesuai dengan pernyataan dengan alasan yang sesuai.

\section{KESIMPULAN DAN SARAN}

\section{Kesimpulan}

Berdasarkan hasil penelitian, analisis data dan pembahasan hasil penelitian tentang kemampuan berpikir kritis siswa dalam pembelajaran IPA di SDN Karang Tengah 11 Kota Tangerang, maka dapat disimpulkan bahwa siswa pada kategori tinggi mempunyai kemampuan berpikir kritis yang baik karena mampu memenuhi semua indikator berpikir kritis. Hal tersebut ditunjukkan dengan siswa mampu menuliskan apa yang diketahui dan apa yang ditanyakan dengan tepat, mampu merumuskan pertanyaan dengan benar, mampu memberikan alasan dengan benar dan lengkap terhadap pendapat yang dikemukakan, mampu membuat kesimpulan yang tepat dari soal yang dikerjakan, mampu memberikan penjelasan yang sesuai dengan soal yang diberikan, serta mampu menentukan suatu tindakan terhadap suatu argumen sesuai dengan pernyataan dengan alasan yang sesuai. Siswa pada kategori sedang mempunyai kemampuan berpikir kritis yang cukup kritis karena hanya mampu memenuhi tiga indikator berpikir kritis. Hal tersebut ditunjukkan dengan siswa 
mampu memberikan alasan terhadap pendapat yang dikemukakan dengan alasan yang sudah mengarah pada soal, siswa mampu menganalisis dan memberikan penjelasan terhadap soal yang disajikan, serta mampu menentukan suatu tindakan terhadap suatu argumen sesuai dengan pernyataan dengan alasan yang sesuai. Siswa pada kategori rendah mempunyai kemampuan berpikir yang kurang kritis karena siswa belum sepenuhnya mampu dalam mengerjakan soal tes berpikir kritis dengan baik sesuai dengan kriteria berpikir kritis. Siswa hanya mampu memenuhi dua indikator berpikir kritis. Hal tersebut ditunjukkan dengan siswa mampu memberikan alasan terhadap pendapat yang dikemukakan dengan alasan yang sudah mengarah pada soal serta mampu menentukan suatu tindakan terhadap suatu argumen sesuai dengan pernyataan dengan alasan yang sesuai.

Kemampuan berpikir kritis mayoritas siswa masih rendah dikarenakan siswa masih kesulitan dalam menjawab dan menyelesaikan soal-soal IPA, dan juga pemahaman siswa terhadap pembelajaran IPA masih belum baik. Siswa sulit diajak untuk berpikir kritis dalam memecahkan soal-soal IPA. Cara berpikir kritis siswa dinilai masih rendah karena siswa dalam pembelajaran cenderung hanya menerima materi yang diajarkan, tanpa mau menelaah lebih lanjut dan kurangnya pemahaman mendalam terhadap materi. Hal ini dikarenakan adanya beberapa faktor yang mempengaruhi kemampuan berpikir kritis siswa yaitu sebagai berikut : Faktor internal yang mempengaruhi siswa dalam berpikir secara kritis ada 5 faktor yaitu (1) kondisi fisik (2) motivasi, (3) kecemasan, (4) perkembangan intelektual, (5) interaksi. Faktor eksternal yang berhubungan dari luar individu berupa lingkungan sosial.

\section{Saran}

Berdasarkan kesimpulan di atas maka peneliti memberikan saran kepada:

1. Bagi siswa

Hendaknya untuk mengetahui kemampuan berpikir kritis siswa diharapkan lebih aktif dan banyak berlatih soal-soal Ilmu Pengetahuan Alam. Selain itu diharapkan siswa aktif bertanya dan berdiskusi dengan guru maupun teman mengenai kesulitan yang dialami supaya dapat menjelaskan atau memberikan alasan yang tepat.

2. Bagi guru

Hendaknya untuk mengetahui kemampuan berpikir kritis siswa, guru dapat menerapkan serta mengembangkan metode pembelajaran yang dapat menunjang untuk meningkatkan kemampuan berpikir kritis siswa.

3. Bagi Sekolah

Hendaknya dapat dijadikan masukan atau pertimbangan dalam kemajuan proses pembelajaran khusunya pembelajaran IPA sehingga mampu meningkatkan kemampuan berpikir kritis siswa.

4. Bagi peneliti

Hendaknya sebelum melakukan penelitian kemampuan berpikir kritis alangkah lebih baiknya untuk mengetahui terlebih dahulu kemampuan siswa dalam pembelajaran IPA. Serta peneliti selanjutnya diharapkan dapat melakukan penelitian dengan 


\section{Sibcatie gowreal}

Jurnal Ilmiah Bioang Sosial, Tkonomi, Budaya, Tekuologi, dan Pendidikan

memberikan perlakuan sehingga dapat meningkatkan atau memperbaiki kemampuan berpikir kritis siswa dalam pembelajaran IPA

\section{DAFTAR PUSTAKA}

Arikunto, S. (2012). Prosedur Penelitian Suatu Pendekatan Praktek. Jakarta: Rineka Cipta. Astuti, S. (2015). Pengaruh Kemampuan Awal dan Minat Belajar Terhadap Prestasi Belajar Fisika. Jurnal Formatif, 68-75.

Faiz, F. (2012). Thinking Skill Pengantar Menuju Berpikir Kritis. Yogyakarta: Suka Press UIN Sunan Kalijaga.

Fanani, Z. (2020). Peningkatan Kemampuan Teknik Dasar Passing Permainan Bola Voli Melalui Metode Drill. Journal Education Research and Development, Vol. 4 No. 1, 111-126.

Fatmawati, H., Mardiyana, \& Triyanto. (2014). Analisis Berpikir Kritis Siswa Dalam

Pemecahan Masalah Matematika Berdasarkan Polya Pada Pokok Bahasan Persamaan Kuadrat. Jurnal Elektronik Pembelajaran Matematika, Vol. 2 No. 2, 65.

Fatmawaty. (2017). Meningkatka Aktivitas dan Hasi Belajar IPA Materi Gaya Magnet

Melalui Metode Inkuiri Terbimbing. Jurnal Ilmiah Pendidikan dan Sosial, Vol. 3 No. $2,8$.

Hisbullah, \& Selvi , N. (2018). Pembelajaran Ilmu Pengetahuan Alam Di Sekolah Dasar. Makasar: Aksara Timur.

Khofiyah, H., Santoso, A., \& Akbar, S. (2019). Pengaruh Model Discovery Learning Berbantuan Media Benda Nyata terhadap Kemampuan Berpikir Kritis dan Pemahaman Konsep IPA. Jurnal Pendidikan, Vol. 4 No. 1, 61-67.

Kumala, F. (2016). Pembelajaran IPA Sekolah Dasar. Kota Malang: Ediide Infografika. Mawardi. (2016). Ilmu Pendidikan. Jakarta: Yayasan Mirqot Ilmiah Al-Itqon.

Meleong, L. (2018). Metodologi Penelitian Kualitatif. Bandung: PT Remaja Rosdakarya. Meriyati. (2015). Memahami Karaktereistik Anak Didik. Bandar Lampung: Fakta Press 1AIN Raden lntan Lampung.

Nafisa, D., \& Wardono. (2019). Model Pembelajaran Discovery Learning Berbantuan Multimedia Untuk Meningkatkan Kemampuan Berpikir Kritis Siswa. Prisma, 854861.

Novita Chandra, S. ., Enawar, E., Sari Ramdhani , I. ., \& Sumiyani, S. (2021). ANALISIS KETERAMPILAN MENULIS KARANGAN DESKRIPSI PADA SISWA KELAS IV DI SD NEGERI PASIRGADUNG 1 KABUPATEN TANGERANG. Berajah Journal, 2(1), 25-31. https://doi.org/10.47353/bj.v2i1.45

Prameswari, S., Suharno, \& Sarwanto. (2018). Inculculate Critical Thinking Skills In Primary Schools. SHEs: Conference Series 1 (1) (2018), 742-750.

Purnomo, H. (2019). Psikologi Pendidikan. Yogyakarta: LP3M Universitas Muhammadiyah Yogyakarta.

Purwanto. (2012). Metodologi Penelitian Kuantitatif Yogyakarya: Pustaka Pelajar. 
Razak, F. (2017). Hubungan Kemampuan Awal Terhadap Kemampuan Berpikir Kritis Matematika Pada Siswa Kelas VII SMP Pesantren Imiim Putri Minasatene. Jurnal Mosharafa, Vol. 6 No. 1, 119.

Rochmad, Agoestanto, A., \& Kurniasih, A. (2016). Analisis Time-Line dan Berpikir Kritis dalam Pemecahan Masalah Matematika pada Pembelajaran Kooperatif Resiprokal. Jurnal Matematika Kreatif-Inovatif, 217-231.

Rustaman, N. (2018). Materi dan Pembelajaran IPA SD. Tangerang Selatan: Universitas Terbuka .

Sugiyono. (2007). Metode Penelitian Kuantitatif Kualitatif dan R\&D. Bandung: Alfabeta. Sugiyono. (2018). Metode Penelitian Kuantitatif, Kualitatif dan R\&D. Bandung: Alfabeta.

Susanto, A. (2013). Teori Belajar dan Pembelajaran di Sekolah Dasar. Jakarta: Kencana Prenadamedia Group.

Susanto, A. (2016). Teori Belajar \& Pembelajaran di Sekolah Dasar. Jakarta: Kencana.

Sutopo, H. B. (2006). Metode Penelitian Kualitatif. Surakarta: Universitas Negeri Sebelas Maret.

Trianto. (2010). Model Pembelajaran Terpadu : konsep strategi, dan Implementasinya dalam kurikulum tingkat satuan pendidikan . Jakarta: Bumi Aksara.

Trimahesri, I., \& Hardini, A. (2019). Peningkatan Kemampuan Berpikir Kritis dan Hasil Belajar Pada Mata Pelajaran Matematika Menggunakan Model Realistic Mathematics Education. Thinking Skills and Creativity Journal, Vol. 2 No. 2, 111120.

Wijaya, I. (2018). Mengembangkan Kecerdasan Majemuk Siswa Sekolah Dasar (SD) Melalui Pembelajaran IPA Untuk Meningkatkan Mutu Lulusan Sekolah Dasar. Jurnal Penjaminan Mutu, Vol. 4 No.2, 147-154.

Wijayanti, R., \& Siswanto, J. (2020). Profil Kemampuan Berpikir Kritis Siswa SMA pada Materi Sumber-sumber Energi. Jurnal Penelitian Pembelajaran Fisika, Vol. 11 No. 1,110 .

Zakiyah, L. \& Lestari. I. (2019). Berpikir Kritis Dalam Konteks Pembelajaran. Klapanunggal Bogor: Erzatama Karya Abadi. 